\title{
CONVENTIONAL APPROACH X LAPAROSCOPIC ABDOMINOPERINEAL RESECTION FOR RECTAL CANCER TREATMENT AFTER NEOADJUVANT CHEMORADIATION: RESULTS OF A PROSPECTIVE RANDOMIZED TRIAL
}

\author{
Sergio Eduardo Alonso Araujo, Afonso Henrique da Silva e Sousa Jr., Fábio \\ Guilherme Caserta Marysael de Campos, Angelita Habr-Gama, Rodrigo Blanco \\ Dumarco, Pedro Paulo de Paris Caravatto, Sergio Carlos Nahas, José Hyppólito \\ da Silva, Desidério Roberto Kiss and Joaquim José Gama-Rodrigues
}

\begin{abstract}
ARAUJO SEA et al. - Conventional approach x laparoscopic abdominoperineal resection for rectal cancer treatment after neoadjuvant chemoradiation: results of a prospective randomized trial. Rev. Hosp. Clín. Fac. Med. S. Paulo 58(3):133140, 2003.
\end{abstract}

OBJECTIVE: The aims of this study were to evaluate the safety and efficacy of laparoscopic abdominoperineal resection compared to conventional approach for surgical treatment of patients with distal rectal cancer presenting with incomplete response after chemoradiation.

METHOD: Twenty eight patients with distal rectal adenocarcinoma were randomized to undergo surgical treatment by laparoscopic abdominoperineal resection or conventional approach and evaluated prospectively. Thirteen underwent laparoscopic abdominoperineal resection and 15 conventional approach .

RESULTS: There was no significant difference $(\mathrm{p}<0,05)$ between the two studied groups regarding: gender, age, body mass index, patients with previous abdominal surgeries, intra and post operative complications, need for blood transfusion, hospital stay after surgery, length of resected segment and pathological staging. Mean operation time was 228 minutes for the laparoscopic abdominoperineal resection versus 284 minutes for the conventional approach ( $\mathrm{p}=0.04)$. Mean anesthesia duration was shorter $(\mathrm{p}=0.03)$ for laparoscopic abdominoperineal resection when compared to conventional approach : 304 and 362 minutes, respectively. There was no need for conversion to open approach in this series. After a mean follow-up of 47.2 months and with the exclusion of two patients in the conventional abdominoperineal resection who presented with unsuspected synchronic metastasis during surgery, local recurrence was observed in two patients in the conventional group and in none in the laparoscopic group.

CONCLUSIONS: We conclude that laparoscopic abdominoperineal resection is feasible, similar to conventional approach concerning surgery duration, intra operative morbidity, blood requirements and post operative morbidity. Larger number of cases and an extended follow-up are required to adequate evaluation of oncological results for patients undergoing laparoscopic abdominoperineal resection after chemoradiation for radical treatment of distal rectal cancer.

DESCRIPTORS: Rectal cancer. Rectum. Laparoscopic resection. Abdominoperineal amputation.

It is undeniable that improvement of surgical techniques resulting from development of mechanical suture devices, better knowledge about dissemination of rectal adenocarcinoma and, more recently, the issue of neoadjuvant treatment through chemo and radiotherapy lead to a considerable increase of sphincter preserving surgery desirable for cure and maintenance of transanal evacuation.

From the Coloproctology Discipline, Digestive Surgery Department, Hospital das Clínicas, Faculty of Medicine, University of São Paulo.

Received for publication on August 18, 2002.
However, abdominoperineal resection (APR), as described by Ernst W. Miles in $1908^{1}$, is still the choice operation for cancers which are very distally located in the rectum, especially when infiltrating anorectal ring and sphincteric system as well as for adenocarcinomas in this localization with incomplete regression after initial 
treatment by means of chemoradiation $^{2}$.

Increasing evidence concerning benefits originated from laparoscopic colorectal surgery such as less morbidity and pain, earlier recovery of bowel function, short hospital stay, and early return to work virtually consolidated this approach for treatment of benign colorectal diseases but doubts persist as to the cost-effectiveness relation in our environment due to high cost of equipments and instruments. Conversely, neoplastic recurrence in incision and trocar sites represents the main barrier to the application of laparoscopic approach for radical surgical treatment of colorectal cancer mainly because the cause of these complications still remains unknown.

APR represents the ideal surgery to be performed by laparoscopic approach, since oncologic dissection is similar to that performed by open access ${ }^{3}$, the lesion is placed below the peritoneal reflection and the tumor manipulation occurs only during the perineal phase, preventing recurrence at trocar sites, there is no need for abdominal incision in order to remove the surgical specimen which makes this surgery truly laparoscopic, and at last, there is no anastomosis to be performed. As a result, several authors have admitted the application of the laparoscopic access in order to cure rectal cancer, whilst for colon cancer, prospective trials are still ongoing and being awaited.

The role of chemoradiation for distal rectal cancer is still under debate. Neoadjuvant chemoradiation impact has been observed. It leads to decreased local recurrence rate, increases sphincter saving procedures and complete regression of some cancers can be observed. Low toxicity of therapeutic regimens has been observed ${ }^{4,5}$.

We aim to evaluate, in a prospective manner, safety and efficacy of laparoscopic abdominoperineal resec- tion (L-APR) compared to conventional approach (C-RAA) for surgical treatment of patients with distal rectal cancer presenting with incomplete response after chemoradiation.

\section{PATIENTS AND METHODS}

Study protcolol was approved by the Ethics and Scientific Committee of our department and full infomed consent was obtained for all patients. Between September 1997 and September 2000, 28 patients with distal rectal adenocarcinoma with pre-operative staging favourable to radical resection by APR were included in this trial and evaluated prospectively. They were randomized to undergo surgical treatment by L-APR or C-APR. Thirteen underwent L-APR and $15 \mathrm{C}-\mathrm{APR}$.

All patients underwent chemoradiation before surgery, as previously described ${ }^{4}$. Cancer persistence was detected either microscopically or macroscopically during the follow-up. Preoperative evaluation and post-operative follow-up were standardized for the 2 groups of patients.

The following variables were prospectively collected for study in the 2 groups : gender, age, body mass index (BMI), history of previous abdominal surgery, duration of surgery (min), duration of anesthesia (min), intra and post operative complications, need for transfusion, length of post operative hospital stay, need for reoperation, number of dissected lymph nodes and length of the pathological specimen, pathological staging, length of followup, and local or distant cancer recurrence.

Statistical analysis comparing the 2 groups (L-RAA and C-RAA) was performed using non-parametric MannWhitney test (for age, BMI, surgery time, anesthesia time, need for hemotransfusion, hospital stay, number of lymph nodes dissected and follow-up), Student's t-test (for length of resected surgical specimen and gender) and Fisher's exact test (for pathological staging, number of blood units and intra and post operative complications). A p value $<0,05$ was considered significant.

Patients underwent operation under general anesthesia, placed in the modified lithotomy position in Trendelenburg with a square cushion beneath the hips, shoulder pads and with $45^{\circ}$ to $60^{\circ}$ leg abduction. A nasogastric tube and urinary catheter were inserted and the anus was closed with a suture. Surgeon and camera assistant were positioned at the right and the second assistant at the left side of the patient.

After pneumoperitoneum had been estabilished, the first trocar was inserted in a peri-umbilical incision and under laparoscopic direct vision the other trocars were inserted. As a routine, $410 / 11 \mathrm{~mm}$ trocars were used: 2 in the right, 1 in peri-umbilical region and another one in the left. According to surgeon's preference, $5 \mathrm{~mm}$ trocars were used in the right. Left trocar incision was located laterally to the site determined by the ostomy therapist for the future colostomy which was placed in trans-rectal position. After cavity inspection, the abdominal phase was initiated by mobilization of the sigmoid colon in its mesenteric peritoneal reflection. According to the surgeon, the harmonic shears were preferably used especially for perirectal dissection. The sigmoid mesentery was dissected medially and the left ureter could be identified on its intersection with the iliac vessels. The mobilized sigmoid was then reflected to the left and an incision was performed medially in the peritoneum from the aorta proeminence to the superior rectal artery creating a communication to the previously dissected area laterally to the sigmoid mesentery. Rectal mobilization aimed to maintain, as far as possible, the integrity of the visceral rec- 
tal fascia and therefore favouring total mesorectal excision as well as to keep intact parietal pelvic fascia preventing damage to autonomic nerves. Inferior mesenteric artery division and control was performed using an endoscopic stapling device in one patient and double clipping for all others. Inferior mesenteric vein was ligated separately through the progression of the dissection laterally in the mesocolon to the sigmoid. The descending sigmoid junction was transected with an endostapling device or at the end of the abdominal phase. The pneumoperitoneum was re-estabilished and the dissection of the rectum proceeded laterally, anteriorly and posteriorly with the help of anterior traction of the sigmoid using a babcock clamp. The dissection continued distally to the closest point to the elevator ani muscles. The pneumoperitoneum was ended and while the colostomy was being matured, the perineal phase of the resection was initiated and accomplished in the usual fashion.

\section{RESULTS}

Of the 13 patients who underwent L-APR, 9 (60\%) were men and among the 15 patients who underwent $\mathrm{C}$ APR, $10(66 \%)$ were men $(p=0.89)$. The mean age was 59.1 for the laparoscopic group and 56.4 for the conventional group $(\mathrm{p}=0.7)$. The mean body mass index for the laparoscopic group was 23.5 and was 25.6 for the conventional group $(\mathrm{p}=0.47)$. Four $(30 \%)$ patients of the laparoscopic group had previous abdominal surgeries in comparison to $5(33.3 \%)$ in the conventional group $(\mathrm{p}=0.31)$. Demographic data are shown in table 1.

Mean operation time was 228 minutes for the laparoscopic group versus 284 minutes for the conventional group $(\mathrm{p}=0.04)$. Mean anesthesia duration was shorter $(\mathrm{p}=0.03)$ for $\mathrm{L}-\mathrm{APR}$ when compared to C-APR: 304 and 362 minutes, respectively.

Intraoperative complications occurred in $2(15,4 \%)$ patients in the laparoscopic group: 1 bladder lesion during perineal dissection and hypotension that responded to volume restoration. In the conventional group, intraoperative complications occurred in 4 patients $(26,7 \%)$ as follows: urethral lesion during perineal dissection in two cases, hypotension in 2 cases and an ureter lesion that was promptly handled. There was no significant difference between the 2 groups $(p=1,0)$.

Blood transfusion was needed in 3 (23.1\%) patients in the L-APR group and in $10(66.6 \%)$ patients in C-APR group. However, the difference was not significant ( $p=0.467-$ Fig. 1). The

Table 1 - Demographic data. number of blood units used for the 2 groups was not significantly different.

There was no need for conversion to open approach in this series.

Postoperative complications were observed in $9(69 \%)$ patients in the LAPR group and in $7(46.7 \%)$ of the CAPR group. There was no significant difference between these rates. Postoperative complications are showed in table 2 .

Hospital stay after surgery was larger for the L-APR patients (mean=10.5 days). However MannWhitney test demonstrated no significant difference between the 2 groups $(\mathrm{p}=0.42)$.

Regarding lymph nodes extent of disection, a mean of 5.5 lymph nodes were dissected by the pathologist phy-

\begin{tabular}{lllc}
\hline & $\begin{array}{l}\text { Laparoscopic } \\
\text { Abdominoperineal } \\
\text { Resection }(\mathrm{n}=13)\end{array}$ & $\begin{array}{l}\text { Conventional } \\
\text { Abdominoperineal } \\
\text { Resection }(\mathrm{n}=15)\end{array}$ & $\mathrm{p}$ \\
\hline Male gender & 9 & 10 & 0,89 \\
Mean age & $59,1(31-75)$ & $56,4(24-78)$ & 0,70 \\
Mean BMI & $23,5(21,7-24,6)$ & $25,6(17,1-38,5)$ & 0,47 \\
Previous abdominal operation & $4(30 \%)$ & $5(33,3 \%)$ & 0,31 \\
\hline
\end{tabular}

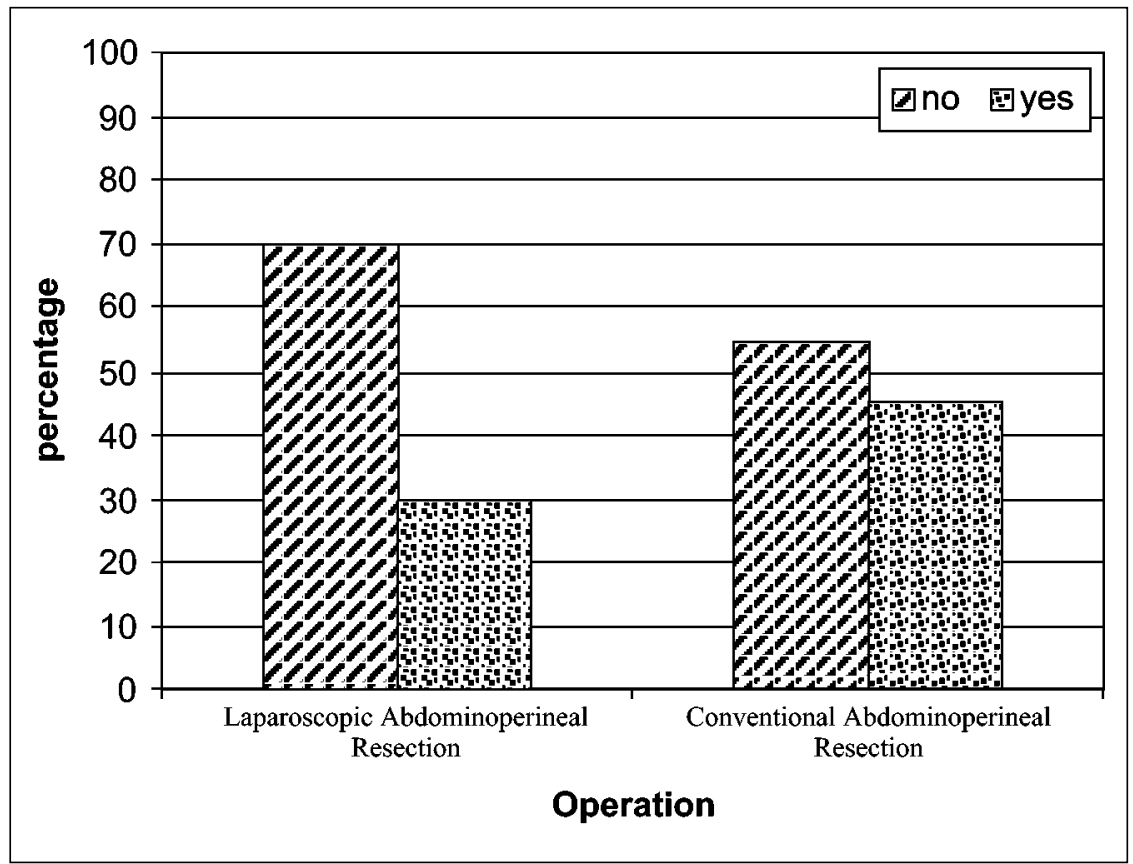

Figure 1 - Need for intraoperative blood transfusion. 
Table 2 - Post operative complications.

\begin{tabular}{lll}
\hline & $\begin{array}{l}\text { Laparoscopic } \\
\text { Abdominoperineal } \\
\text { Resection }(\mathrm{n}=13)\end{array}$ & $\begin{array}{l}\text { Conventional } \\
\text { Abdominoperineal } \\
\text { Resection }(\mathrm{n}=15)\end{array}$ \\
\hline Dehiscence of perineal wound & 4 & 3 \\
Late bowel function recovery & 1 & 3 \\
Urinary retention & 1 & 1 \\
Perineal hernia & 2 & 0 \\
Pulmonary infection & 1 & 0 \\
Male gender & $9(69 \%)$ & $7(46,7 \%)$ \\
\hline
\end{tabular}

$\mathrm{p}=0,47$

sician in the L-APR group and 11,9 in the C-APR. Theses results show that the number of lymph nodes harvested in the laparoscopic group was smaller $(\mathrm{p}=0.04)$. The mean length of colorectal resected segment was $26 \mathrm{~cm}$ in the L-APR and $33 \mathrm{~cm}$ in the C-APR ( $\mathrm{p}=0.349)$.

The distribution of the patients according to the pathological staging (Astler-Collins) was similar for the groups ( $\mathrm{p}=0.25-$ graphic 2$)$. Data are shown in table 3 .

After a mean follow-up of 47.2 months and with the exclusion of 2 patients in the conventional APR who presented with unsuspected synchronic metastasis during surgery, local recurrence was observed in 2 patients in the conventional group and in none in the laparoscopic group.

\section{DISCUSSION}

The perspective of performing LAPR which from the technical point of view constitutes truly laparoscopic operation - impelled colorectal surgeons to offer minimally invasive surgery to patients that will handle definite colostomies.

It has been consistently demonstrated that L-APR represents feasible and safe operation with benefits already observed by several authors. However, it is recognized that facing the excellent results which are obtained with the C-APR - especially when performed by surgeons skilled in colorectal dissection and with large experience -, laparoscopic colorectal surgery for cancer was judged inadequate or superfluous. Controversy was due to uncertainty of oncologic long term results; the enigma of trocar
Table 3 - Pathological data. site recurrence; the perception of a steep learning curve which demands significant dedication of the surgeon; the search for adequate animal models to practice; larger occurrence of complications during initial experience and finally, the elevated cost still associated to the method.

Decanini and cols. ${ }^{6}$ in a study performed in fresh corpses, demonstrated that the L-APR is feasible according to oncological principles. We understand that when sphincter ablation is indicated to reach cure of rectal cancer, total mesorrectal excision ${ }^{7}$ stands as a main technical principle to be pursuited during abdominal phase associated to preservation of radial mar-

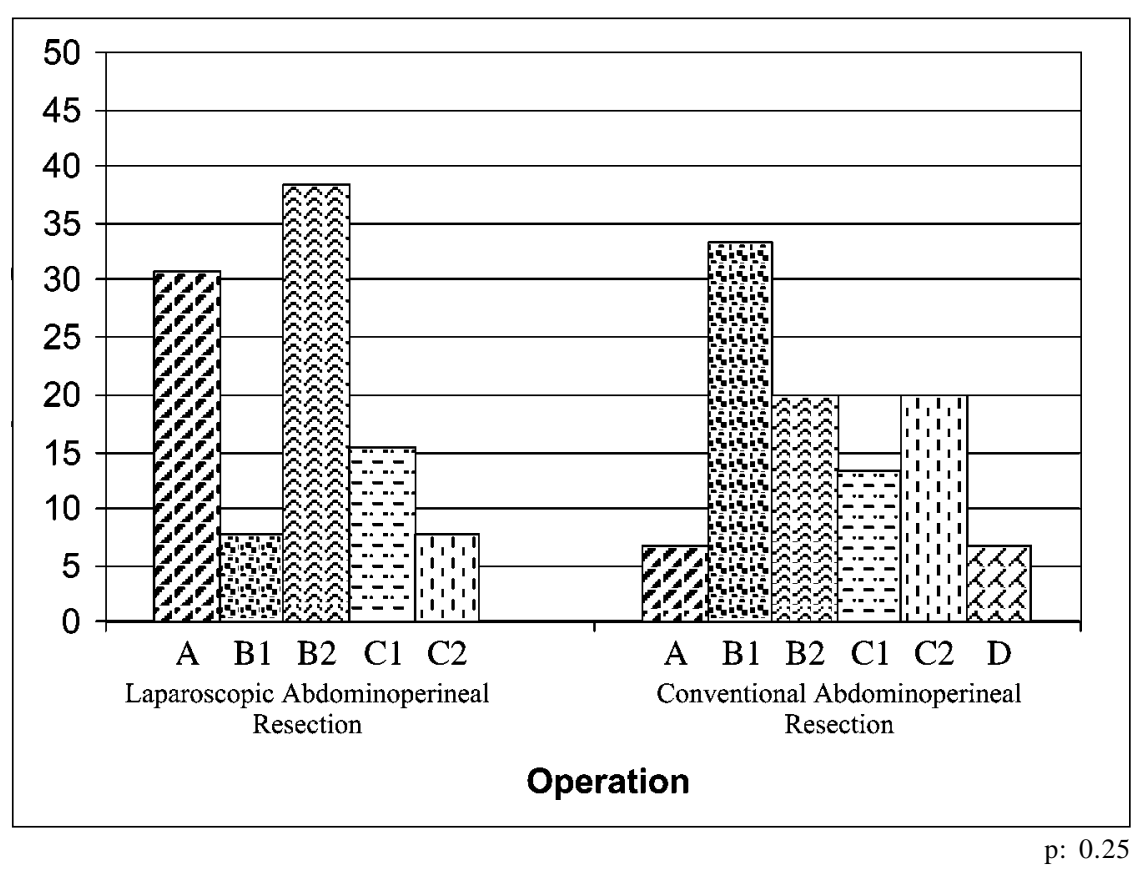

Figure 2 - Patients distribution according to pathological staging.

\begin{tabular}{clll}
\hline & $\begin{array}{l}\text { Laparoscopic } \\
\text { Abdominoperineal } \\
\text { Resection } \quad(\mathrm{n}=13)\end{array}$ & $\begin{array}{l}\text { Conventional } \\
\text { Abdominoperineal } \\
\text { Resection }\end{array}$ & $\mathrm{p}=15)$ \\
\hline Mean extention of resected specimen & $26 \mathrm{~cm}$ & $33 \mathrm{~cm}$ & 0,34 \\
Mean number of disected lymph nodes & 5,5 & 11,9 & 0,04 \\
Astler-Coller A & 4 & 1 & \\
B1 & 1 & 5 & \\
B2 & 5 & 3 & \\
C1 & 2 & 2 & \\
C2 & 1 & 3 & \\
D & 0 & 0 & \\
\hline
\end{tabular}


gin. Perineal phase is accomplished during L-APR exactly as during C$\mathrm{APR}^{8,9}$.

In order to reduce local recurrence rates and improve survival after rectal cancer diagnosis, several treatment modalities combining surgery, radio and chemotherapy were designed ${ }^{2}$. Neoadjuvant chemoradiation leads to cancer mortality decrease, improves ressecability through tumoral downstaging, increases sphincter preservation and reduces local recurrence 5. In our hospital, a regimen of 5fluoracil/leucovorin therapy associated to external beam radiotherapy (5040 Cgy) has been used as first modality treatment with intention to cure patients bearing distal rectal adenocarcinoma stages I, II and III of the TNM classification since $1991^{2}$.

After some progress in the learning curve in colorectal surgery and based on good results obtained with the laparoscopy approach for APR operations ${ }^{10}$, we decided to initiate a prospective and randomized trial in order to assess results of safety and efficiency of L-APR in comparison to the conventional approach for patients who presented with incomplete response to chemoradiation.

Demographic data results of gender, age, BMI and history of previous abdominal operation are showed in table 1. It can be noted that in spite of the small number of patients, table randomization was successful in not selecting patients of the male gender, obese or with previous surgeries for the conventional approach. Under several aspects, APR stands as the ideal operation to be performed by video approach. Once the experience is achieved and newly developed equipment such as the harmonic scalpel is used, obesity, male gender and previous abdominal surgery no longer represent a contraindication to the laparoscopic approach.

Regarding the results of longer sur- gical time and anesthesia duration associated to the conventional approach, we understand there is a bias in this result. Surgical team in charge of performing L-APR when sorted was often the same in opposition to the conventional group, where different surgical teams performed the operation. In accordance with results observed by other authors, it is likely that operation and anesthesia time are similar between the two study groups after initial cases are performed ${ }^{6,11-18}$.

There are specific intraoperative complications of the laparoscopic approach, such as injury of abdominal wall vessels, refractory hypercapnia, intra abdominal vessels injury, bowel perforation, and bladder and ureter lesions mainly due to inadequate anatomic recognition. The majority of these complications can be prevented and occur during the initial phase of expertise. Intraoperative complications have occurred with similar frequency in the 2 studied groups, and could not be associated to the surgical access. Attentive surgical technique under good endoscopic view, motivation of the surgical team and the use of $30^{\circ}$ telescopes may be related to less intraoperative morbidity.

Some authors attribute to the video approach, a potential to reduce bleeding and need for blood transfusion $11,13,15,18$ if compared to the conventional access. In APR, the perineal stage of the operation requires special attention to hemostasis. As this phase is conducted in the same way in both groups of study, we believe in the validity of the results of homogeneity of blood requirements in L-APR and CAPR (Fig. 1).

In a previous report ${ }^{10}$ focusing the initial experience of this staff with LAPR we observed the need for conversion to the open approach in a female patient due to a large uterus. We believe that this conversion is a phenomenon that occurs early in the video surgery experience either with cholecistectomy, antireflux surgery or colectomy. Familiarization with endoscopic disection and a more experienced staff perhaps may be the main determinants of a decrease in conversion rate. Nevertheless, specific complications may be better managed by laparotomy, such as ureter lesions, posterior bladder lesions and some cases of intra abdominal bleeding. In these series, no conversions were needed which is comparable to other studies with reported conversion rates ranging from 0 to $40 \%^{3,8,9,12,13}$.

Post operative morbidity was similar in both groups and it does not seem to be associated to surgical access (Table 2). A perineal hernia represents a relatively rare phenomenon after the APR and has occurred early in this series in 2 patients submitted to the LAPR. Both of them required re-operation in order to correct the defect. Although it was initially associated to the video approach, this complication is not associated to the access. Closure of the pelvic peritoneum, which may be accomplished more frequently during conventional access, was attributed by some surgeons as a protection factor against perineal hernias. However, dehiscence of pelvic peritoneum closed under tension may lead to the herniation with increased risk of small bowel incarceration. As a result, in some cases of L-APR, we have started executing the reinforcement of the perineal closure applying bovine pericardium prosthesis. Since then, this complication no longer happened; however, we believe that this caution should be reserved to selected cases, in spite of an easy execution associated to no complication in three cases.

One of the most popular benefits associated to video surgery was shorter hospital stay ${ }^{6,12-18}$. In the present study casuistry we could not verify this fact. In fact, medium duration of post operative stay was superior in the group sub- 
mitted to L-APR although this result has not reached significance. We attributed this result to 2 reasons: 1) small number of patients, and 2) that morbidity and disability for post operative APR patients results from the perineal wound. We observed in abdominal surgeries performed by laparoscopy such as anterior resection for megacolon or diverticular diseases a faster recovery for patients submitted to video surgery. In the APR operation, however, morbidity is related to perineal dissection, making it more difficult to demonstrate shorter hospital stay .

Since the status of resected lymph nodes is related to prognosis after curative colorectal cancer surgery, it is not a surprise that this aspect constitutes an endpoint of criterial evaluation. Although widely mentioned in the past ${ }^{6,13,17-19}$, the number of excised lymph nodes does not suitably represent extension of dissection, since the number of lymph nodes identified in the surgical specimen depends on the pathologist physician, who is processing the specimen and, per se, does not allude to the localization of these lymph nodes, whether if close to arterial ligation, in retroperitoneal position or simply epicolics. With respect to APR, several clinical trials involving a larger number of patients ${ }^{6,8,11-18} \mathrm{dem}$ onstrated similarity in the extent of lymphadenectomy provided by the LAPR and C-APR. In our small series of cases, we observed a smaller mean number of disected lymph nodes in patients submitted to the laparoscopic approach $(5,5$ vs 11,9$)$. We believe that this evidence, although generated from a randomized trial, does not reflect the reality and represents a bias resulting from the small number of evaluated patients. Also, this phenomenon may reflect a differential response of tumoral regression with cause still unknown. In the group of patients submitted to the L-APR, no lymph nodes were detected at all in the surgical specimen in 4 cases against 2 cases in the conventional group. Perhaps differences in the pathology department staff involved in the specimen dissection or methodological differences in order to identify lymph nodes may explain these results . On the other hand, the evaluation of the length of excised intestinal segment, which was similar in both groups, indicates that the extent of the operations was equal.

Evaluating the risk most commonly related to local recurrence after curative treatment of the rectal cancer, we may outline as variables of strong or independent correlation with this unfavourable course: advanced pathological staging, incomplete resection (compromised margins), no adjuvant perioperative treatment or little response to tumor neoadjuvant treatment, tumor aneuploidy, p53 hyper expression, among others ${ }^{20-30}$. Fleshman et al. ${ }^{12}$, in a trial comparing L-APR and C-APR with a total of 194 cases, did not observe differences between the 2 groups concerning cancer neoplastic recurrence after mean follow up of 19 and 24 months, respectively. Milsom et al. ${ }^{15}$ obtained similar re- sults although they concluded that a longer follow-up time was required. In our study, excluding patients with liver metastasis, we detected local recurrence in 2 patients submitted to $\mathrm{C}$ APR and in none in the laparoscopic group. Due to the small number of cases and to advanced pathological staging of these patients even after chemoradiation treatment, we believe that recurrence in this series can not be associated to surgical access. In order to verify this question, we are awaiting the ongoing results of larger number of patients as well as enlargement of post operative follow-up.

We must have caution when considering the strength of the evidences here, in spite of the randomization. The data were collected in a small scale ${ }^{31}$ due to a small number of cases. Since the majority of the available experiences are not controlled and similarly demand follow-up, we have decided to submit our data in order to enlarge scientific evidence and even to set up systematic reviews and meta analysis.

\section{CONCLUSIONS}

We conclude that L-APR is feasible, similar to C-APR concerning surgery duration, intra operative morbidity, blood requirements and post operative morbidity. Larger number of cases and an extended follow-up are required to adequate evaluation of oncological results for patients undergoing L-APR after chemoradiation for radical treatment of distal rectal cancer.

\section{RESUMO}

ARAUJO SEA e col. - Amputação do reto convencional $\mathrm{x}$ laparoscópica no tratamento do câncer do reto distal após quimioirradiação neoadjuvante - resultados de estudo prospectivo e randomizado. Rev. Hosp. Clín. Fac. Med. S. Paulo 58 (3):133-140, 2003.
OBJETIVO: Comparar os resultados de eficácia e segurança do emprego da operação de amputação do reto por via laparoscópica e por via con- 
vencional no tratamento cirúrgico de pacientes com câncer do reto distal que apresentaram resposta incompleta a quimioirradiação pré-operatória.

MÉTODO: Vinte e oito pacientes com adenocarcinoma de reto distal foram randomizados para se submeter à amputação do reto por via laparoscópica ou à amputação do reto por via convencional. Treze pacientes submeteram-se à amputação do reto por via laparoscópica e 15 à amputação do reto por via convencional .

RESULTADOS: Não houve diferença significativa $(\mathrm{p}<0,05)$ no que se refere a: sexo, idade, índice de massa corpórea, história pessoal de operação abdominal, complicações intra e pós operatórias, necessidade de hemotransfusão, tempo de internação hospitalar após a operação, extensão da peça ressecada e estadiamento anatomopatológico. O tempo operatório médio foi de 228 minutos para amputação do reto por via laparoscópica versus 284 minutos para amputação do reto por via convencional $(p=0,04)$. A duração média de anestesia foi menor $(\mathrm{p}=0,03)$ para amputação do reto por via laparoscópica quando comparado com amputação do reto por via convencional: 304 e 362 minutos respectivamente. Não foram realizadas conversões nos pacientes submetidos à amputação do reto por via laparoscópica . Após seguimento médio de 47,2 meses e excluindo-se dois pacientes do grupo amputação do reto por via convencional que no intra-operatório apresentavam metástases sincrônicas, observouse recidiva local em dois pacientes no grupo amputação do reto por via con- vencional e em nenhum do grupo amputação do reto por via laparoscópica.

CONCLUSÕES: Concluímos que a amputação do reto por via laparoscópica é exequível nos mesmos moldes que a amputação do reto por via convencional no que se refere à duração da operação, morbidade intra-operatória, perda sangüínea e morbidade pós-operatória. Há necessidade de maior casuística e seguimento ainda não disponíveis para a adequada avaliação da radicalidade oncológica, ocorrência de recidiva e sobrevida para pacientes submetidos a tratamento cirúrgico do câncer do reto por amputação do reto por via laparoscópica .

DESCRITORES: Câncer do reto. Ressecção. Laparoscopia. Amputação abdominoperineal.

\section{REFERENCES}

1. MILES EW - A method of performing abdominoperineal excision for carcinoma of the rectum and the terminal portion of the pelvic colon. Lancet 1908, 2:1812-13.

2. HABR-GAMA A, DE SOUZA PM, RIBEIRO U JR et al. - Low rectal cancer: impact of radiation and chemotherapy on surgical treatment. Dis Colon Rectum 1998; 41:1087-96.

3. DECANINI C, MILSOM JW, BÕHM B et al. - Laparoscopic oncologic abdominoperineal resection. Dis Colon Rectum 1994; 37:552-8.

4. NICCHOLLS RJ, RITHCIEJK, WASWORTH J et al. - Total excision or restorative resection for carcinoma of the middle third of the rectum. Br J Surg 1979; 66:625-7.

5. CAMPOS FG, HABR-GAMA A - Câncer do reto distal: radioterapia e quimioterapia: quando e como? In: HABR-GAMA A, GAMARODRIGUES J, CECCONELLO I et al. - Atualização em Cirurgia do Aparelho Digestivo e em Coloproctologia. São Paulo, Frôntis Editorial, 2001. p. 323-32.

6. DARZI A, LEWIS C, MENZIES-GOW $\mathrm{N}$ et al. - Laparoscopic abdominoperineal excision of the rectum. Surg Endosc 1995;9:414-7.

7. MCCALL JL - Total mesorectal excision: evaluating the evidence. Aust N Z J Surg 1997; 67:599-602.
8. CHINDASUB S, CHARNTARACHARMNONG C, NIMITVANIT C et al. - Laparoscopic abdominoperineal resection. J Laparoendosc Surg 1994;4:17-21

9. LROATULAM AJ, AGACHAN F, ALABAZ O et al. - Laparoscopic abdominoperineal resection for anorectal cancer. Am Surg 1998;64:12-8

10. SOUSA JR AH, HABR-GAMA A, CAMPOS FG et al. Laparoscopic abdominoperineal resection of rectum. Analysis of 18 cases. Rev Hosp Clín Fac Med S Paulo, 1958; 53: 2428 .

11. FLESHMAN JW, WEXNER SD, ANVARI M et al. - Laparoscopic versus abdominal perineal resection for cancer. Dis Colom Rectum 1999; 42(7): 930-9.

12. RAMOS JR, PETROSEMOLO RH, VALORY EA et al. Abdominoperineal resection: laparoscopic versus conventional. Surg Laparosc Endosc, 1997; 7(2):148-152.

13. SEOW-CHOEN F, EU KW, HO YH, et al. - A preliminary comparison of a consecutive series of open versus laparoscopic abdominoperineal resection for rectal adenocarcinoma. Int J Colorectal Dis 1997; 12(2):88-90. 
14. MILSOM JW, BOHM B, HAMMERHOFER KA et al. - A prospective randomised trial comparing laparoscopic versus conventional techniques in colorectal surgery: a preliminary report. J Am Coll Surg 1998; 187(1):46-54.

15. LARACH SW, SALORNON MC, WILLIAMSON PR et al. Laparoscopic assisted abdominoperineal resection. Surg Laparose Endosc 1993; 3:115-8.

16. WU JS, BIRNBAUM EH, FLESHMAN JW - Early experience with laparoscopic abdominoperineal resection. Surg Endosc 1997; 11: 449-55.

17. FRANKLIN ME JR, ROSENTHAL D, NOREM RF - Prospective evaluation of laparoscopic colon resection versus open colon resection for adenocarcinoma :a multicenter study. Surg Endosc $1995 ; 9: 81$ 1-6.

18. FLESHMAN JW, NELSON H, PETERS WR et al. - Clinical Outcomes of Surgical Therapy Study Group - Early results of laparoscopic surgery for colorectal cancer: retrospective analysis of 372 patients treated by Clinical Outcomes of Surgical Therapy (COST) Study Group. Dis Colon Rectum 1996; 39:S53-8.

19. GEIS WP, KIM C - Improved efficiency in laparoscopic abdominoperineal resection: the Kim-Geis approach. Int Surg 1994; 79:226-7.

20. SATO T, NISHIMURA G, FUSHIDA S et al. - Evaluation of p53, Ki-67 and DNA ploidy in both primary rectal carcinomas and locally recurrent tumors. Oncol Rep 1998; 5(5):1225-9.

21. DESAI GR, MYERSON RJ, HIGASHIKUBO R et al. - Carcinoma of the rectum. Possible cellular predictors of metastatic potential and response to radiation therapy. Dis Colon Rectum 1996; 39(10): 1090-6.

22. ADELL G, SUN XF, STAL O et al. - p53 status: an indicator for the effect of preoperative radiotherapy of rectalcancer. Radiother Oncol 1999; 51(2):169-74.
23. SCHWANDNER O, SCHIEDECK TH, BRUCH HP et al. - p53 and Bcl-2 as significant predictors of recurrence and survival in rectalcancer. Eur J Cancer 2000; 36(3):348-56.

24. NEHLS O, KLUMP B, HOLZMANN K et al. - Influence of p53 status on prognosis in preoperatively irradiated rectal carcinoma. Cancer. 1999 15; 85(12):2541-8.

25. LAMMERING G, TAHER MM, GRUENAGEL HH et al. Alteration of DNA ploidy status and cell proliferation induced by preoperative radiotherapy is a prognostic factor in rectal cancer. Clin Cancer Res 2000; 6(8):3215-21.

26. MORAN MR, ROTHENBERGER DA, GALLO RA et al. Multifactorial analysis of local recurrences in rectal cancer, including DNAploidy studies: a predictive model. World J Surg 1993; 17(6):801-5.

27. LIANG JT, CHENG YM, CHANG KJ et al. - Reappraisal of K-ras and p53 gene mutations in the recurrence of Dukes' B2 rectal cancer after curative resection. Hepatogastroenterology 1999; 46(26):830-7.

28. CHANG KJ, ENKER WE, MELAMED M - Influence of tumor cell DNA ploidy on the natural history of rectal cancer. Am J Surg 1987; 153(2):184-8.

29. ROSEANO M, TUROLDO A, BALANI A et al. - DNA ploidy and cell kinetics in cancer of the rectum]. Ann Ital Chir 1994; 65(3):319-29. Italian.

30. WIGGENRAAD R, TAMMINGA R, BLOK P et al. - The prognostic significance of p53 expression for survival and local control in rectal carcinoma treated with surgery and postoperative radiotherapy. Int J Radiat Oncol Biol Phys 1998; 41(1):29-35.

31. COLLINS R, MACMAHON S - Reliable assessment of the effects of treatment on mortality and major morbidity, I: clinical trials. Lancet 2001; 357: 373-80. 